Marcin Kafar

\title{
AUTO/BIOGRAFICZNE ASPEKTY PRAKTYK POZNAWCZYCH PRZESTRZENIE DO-ŚWIADCZEŃ I REFLEKSJI
}

Każde poznanie naukowe jest $w$ pierwszym rzędzie rozczarowaniem, bo zaspokajajac zdziwienie niszczy podziw. Lecz $w$ nasteppnym etapie stwarza każde rozwiązanie szereg nowych pytań, dlatego po rozczarowaniu poznawczem, idzie nowy, głębszy podziw.

\section{Nauka jako proces do-świadczeniowy - od Józefa Tischnera do Pierre'a Bourdieu}

Rozpoczynając pisanie tego tekstu mam w pamięci definicję, jaka swego czasu zaproponował Józef Tischner, zwracający uwagę na swoisty potencjał ruchu oraz na współbieżna $z$ nim praktykę działania, skrywająca się w aktach do-świadczeniowych. „Polskie słowo d oś wi a d c ze ni e - pisał filozof dialogu - składa się $z$ dwóch elementów: do i świadczenie. Pierwszy wskazuje na dążenie, drugi na świadectwo. Wzięte razem znaczą: dochodzenie do świadectwa" (Tischner 2006: 19; rozstrzelenie w oryginale). Umiejscowione w takim kontekście znaczeniowym słowo „doświadczenie” (jak wiadomo, u samego Tischnera posiada ono wyraźne zabarwienie religijne) zawiera istotna dla moich dalszych rozważań cechę, a mianowicie symetryczność istniejąca między pokonywana droga (dochodzeniem do w języku Tischnerowskim) a jej 
celem (czyli osiaganiem świadomości, która możemy traktować jako zwieńczenie przebytej już drogi). O pokonywanie jakiej drogi jednak by tu chodziło i do zyskiwania świadomości czego miałaby nas ona prowadzić?

Aby nieco bardziej uściślić tę kwestię, sięgnę po wsparcie ze strony Pierre'a Bourdieu, który w rewelatorskim tekście pt. Zaproszenie do socjologii refleksyjnej obnażył sztampowy charakter praktyki akademickiej, stwierdzajac: „Homo academicus lubi rzeczy skończone. Jak niedzielni malarze, usuwa ze swoich prac ślady pędzelka, tusze i retusze”; dalej zaś Bourdieu wyznaje: „Zdarzyło mi się odczuć wielki niepokój, gdy odkryłem, iż malarze tacy jak Couture, mistrz Maneta, pozostawili po sobie wspaniałe szkice, bardzo już bliskie malarstwu impresjonistycznemu - które się zwróciło przeciwko nim - i że często psuli swoje dzieła sądząc, że wprowadzają końcowe poprawki wymagane przez wzór moralny pracy dobrze wykonanej, starannie wymuskanej, której wyrazem była estetyka akademicka" (Bourdieu, Wacquant 2001: 216-217). Cóż wszakże mielibyśmy zyskać w zamian? Otóż, według autora Reguł sztuki, alternatywą dla uległości wobec dominacji formy skończonej jest skupienie się na stanie rodzenia się, ksztattowania i przekształcania określonych idei, konceptów, teorii, rozstrzygnięć badawczych i towarzyszacych im metodologii. Stan ten odpowiada - posłużę się zaproponowaną w pierwszym akapicie nomenklatura - warstwie do-świadczeniowej i zwiąany jest $z$ przebywaniem drogi, a więc także, w świetle tego, co zasugerowałem wyżej, ze stopniowym zyskiwaniem świadomości na temat podejmowanych rozwiązań badawczych i skutków, jakie moga one wywołać.

Propozycja Pierre'a Bourdieu jest mi bliska przede wszystkim dlatego, że próbuje się w niej podnieść rangę poznawcza rzeczy źródłowo przypisanych do zaplecza uprawiania nauki, do jej rewersu w postaci refleksywnego namysłu nad stosowanym warsztatem badawczym $\mathrm{w}$ połączeniu $\mathrm{z}$ jego przełożeniem na radzenie

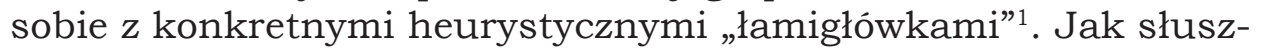
nie ujął to Loïc J.D. Wacquant, znawca regul rządzacych strategia uprawiania nauki przez Bourdieu, tego ostatniego interesuje głównie właściwy mu modus operandi, nie zaś opus operatum (Wacquant 2001: 3). Intrygujący, a zarazem kluczowy pod pewnymi względami jest uwypuklony w tym wypadku aspekt realnej

${ }^{1}$ Zwrotu „łamigłówka” używam w znaczeniu nadanym mu przez Thomasa S. Kuhna (por. m.in. 1985: 476, 2003: 240). 
wagi działań marginalizowanych, często też całkowicie ignorowanych w obrębie akademickiego habitusu. Logika, jaka posługuje się francuski filozof prowadzi go m.in. do konkluzji mówiącej, iż wyodrębnienie $z$ jednolitego tła oraz przeniesienie w obręb zagadnień pierwszoplanowych spraw powszechnie uznawanych za drugorzędne, może się okazać kamieniem probierczym twórczości naukowej. Ponownie odwołam się do wykładu Bourdieu, który przekonuje: „Tym, co się naprawdę liczy, jest sposób skonstruowania przedmiotu, a potęga metody myślenia w niczym nie przejawia się lepiej, jak w zdolności do stworzenia z przedmiotów społecznie mało znaczących przedmiotu nauki. Albo, co na jedno wychodzi, w umiejętności naukowej rekonstrukcji wielkich, społecznie ważnych przedmiotów, dzięki ujęciu ich pod innym, nioczekiwanym katem widzenia. (...) W tym sensie socjolog jest dziś w sytuacji podobnej do tej, w jakiej - mutatis mutandis - znajdowali się Manet czy Flaubert, którzy, aby w pełni sprostać świeżo wynalezionemu przez siebie sposobowi konstruowania rzeczywistości, stosowali go także wobec obiektów tradycyjnie wykluczonych ze sztuki akademickiej, poświęconej wyłącznie osobom i rzeczom społecznie naznaczonym jako ważne. I zdobyli sobie etykietkę "realistów" (Bourdieu, Wacquant 2001: 218).

\section{W stronę „sposobu działania" - projekt „Perspektywy Biograficzne" jako tło ideowe powstania publikacji}

Decydująca o oryginalności stanowiska Bourdieu intencja koncentrowania się na „sposobie działania”, a nie na „dziele dokonanym" (dzieło przecież budowane jest stale od nowa poprzez jego twórcze permutacje), znakomicie współgra $z$ intencja, jaka przyświecała mi, kiedy pięć lat temu podjąłem się wcielenia w życie projektu badawczego pod hasłem „Perspektywy Biograficzne”. Pomysł ten, co w detalach objaśniałem przy innej okazji (por. Kafar 2011a, 2013a), udało się zapoczątkować dzięki szczęśliwej koincydencji, która łącząc korpus doświadczeń osobistych i relacji interpersonalnych sporej grupy autorów $z$ odpowiednim zapleczem instytucjonalnym, pozwoliła na przekucie mocno wcześniej zindywidualizowanych i rozproszonych dyscyplinarnie linii myślowych w spójna tekstualnie, wielogłosowa materię słowa. Na takiej oto bazie - opisując rzecz w największym skrócie - powstały cztery pierwsze tomy 
wieńczące wykonaną do tej pory pracę w ramach inicjatywy „Perspektywy Biograficzne" (por. Kafar 2011b, 2013b, 2013c; Kafar, Modrzejewska-Świgulska 2013)).

Chciałbym w tym momencie powtórzyć ważną ideę, wyłuszczoną w programowym tekście pt. Around „Biographical Perspectives”. An introduction (Kafar 2013a). Szkicujac tam tło konceptualne dla badania biografii naukowych - głównego pola zainteresowań, jakie planujemy rozwijać w projekcie "Perspektywy Biograficzne" - pisałem: „(...) dyskursy zaczynaja kiełkować i rozpleniać się w chwilach zyskiwania przez nas świadomości co do "braku» czegoś. Dyskurs auto/biograficzny w proponowanym wariancie jest więc - per analogiam do innych wyłaniających się dyskursów - efektem odczuwania braku" (Kafar 2013a: 13-14; tłum. własne - M.K.). Tom 1 serii „Perspektywy Biograficzne” (Biografie naukowe. Perspektywa transdyscyplinarna) oraz tom I serii "Biographical Perspectives” (Scientific biographies. Between the "professional" and "non-professional" dimensions of humanistic experiences) zostały potraktowane jako wstępne (choć w dużym stopniu już domknięte, czyli dojrzałe intelektualnie) próby przekroczenia owego „braku”; były wyrazem dążeń do przełamania milczenia (więc także znalezienia języka) odnośnie do niewystarczająco zauważanego dotychczas problemu napięcia istniejącego między dwoma wymiarami biografii: wymiarem doświadczeń „pozanaukowych” podmiotu indywidualnego i wymiarem angażujaccych go profesjonalnie praktyk „naukowych”, co odpowiada sytuacji splotów różnych aspektów biografii „oficjalnej” i „nieoficjalnej”. W tym samym programowym artykule (Around „Biographical Perspectives”) nadmieniałem też: „Przed “Perspektywami Biograficznymi" stawiamy (...) bardzo ambitne zadanie rozbudzania "wyciszonych" do tej pory głosów, poprzez interpretacje przeszłych wydarzeń chcemy odkrywać podskórne znaczenia tekstów, a także dążyć do pokazania, że nauki nie uprawiają wyabstrahowane ze swiata istoty, ale osoby - usytuowani kulturowo i społecznie żywi ludzie. W tak zakreślonym horyzoncie starać się będziemy realizować zintegrowany program wydobywania na światło dzienne "dogłębnego ruchu" myśli, myśli dla scalenia których najbardziej

2 Motyw odczuwania „braku” lub też „niedostatku” zaczerpnąłem ze skłaniającego do medytacji fragmentu pisma pt. O Bogu, który nawiedza myśl Emmanuela Lévinasa, gdzie stawiane są fundamentalne pytania: „Dlaczego mówimy? Czy dlatego, że istota myśląca ma coś do powiedzenia? Ale dlaczego miałaby to powiedzieć? Dlaczego nie wystarczyłoby jej pomyśleć to, co myśli? Czyż nie mówi tego, co myśli właśnie dlatego, że wykracza poza to, co jej wystarcza, i dlatego, że język niesie ten dogłębny ruch?” (Lévinas 2008: 252). 
adekwatną wydaje się być metafora kłacza. Ona to bodaj najlepiej oddaje zalążkowy stan idei "do drążenia", "do pogłębienia", "do przebadania", jednocześnie pozwalając uciec od tyranii obiegowych haseł, wypłaszczających tradycyjny naukowy dyskurs (co sugerował w swoim Dzienniku metafizycznym Gabriel Marcel (1987))" (Tamże: 15; tłum. własne - M.K.; kursywa w oryginale).

\section{W stronę „sposobu działania" - podglebie myślowe horyzontu tematycznego publikacji}

Wyraźnie wyczuwalny w powyższym cytacie tryb manifestu badawczego pozostaje aktualny. Proponowana w nim strategia wychodzenia naprzeciw kolejnym „brakom” (poprzez „drążenie”, „pogłębianie”, „badanie”) wpisuje się w Bourdieu’ański styl uprawiania nauki jako „sposobu działania”. Przedkładany Czytelnikowi tom jest zaś kolejna odsłona realizacji tej strategii; stanowi kontynuację badań nad biografiami naukowymi, badań podejmowanych przez co do swego składu niestała grupę naukowców, o doświadczeniach wyrastajacych $z$ pedagogiki, antropologii kulturowej, etnologii, socjologii, historii, literaturoznawstwa, kulturoznawstwa, filozofii oraz nauki o komunikacji społecznej. Książka ta powstawała długo. Jej zaczynem stały się wystapienia kilkorga $z$ Autorów współtworzących wraz ze mną merytoryczną warstwę konferencji pt. Autobiografia - biografia - narracja. Perspektywy biograficzne $w$ praktyce badawczej/Autobiography - biography - narration. Biographical perspectives in research practice (Lódź 29-30 maja 2012)3. W trakcie tejże konferencji pojawiły się referaty Edyty Januszewskiej oraz Izabeli Lewandowskiej (Badacz wobec badanego. Różne dyscypliny - jedna perspektywa), Marcina Kafara („Prawdziwe zmyślenie" w praktyce antropo-logicznej. Od literatury do doświadczenia „bycia $w$ terenie”), Izabeli Kamińskiej (O (nie)udanej próbie odnalezienia sie $w$ roli „praktykujacego badacza” - refleksja $z$ pola praktyki), Martyny Pryszmont-Ciesielskiej („Ja” badacza w podejściu auto/biograficznym. Ujęcie praktyczne), Michała Rydlewskiego (O pomieszaniu życia z literatura. Wokół metafory „prawdziwego zmyślenia” jako autokreacji Marka Hłaski), Danuty Urbaniak-Zając

${ }^{3}$ Konferencja ta została zorganizowana pod patronatem instytucjonalnym Katedry Badań Edukacyjnych Uniwersytetu Łódzkiego i była trzecią odsłoną łódzkich spotkań biograficznych. 
(Badacz $w$ badaniach empirycznych - refleksja metodologiczno-biograficzna), Filipa Wróblewskiego (Ku sobie i z powrotem. Etnopoetyka jako próba autobiograficzna) oraz Andrzeja P. Wejlanda (Spojrzeć na swiat jak antropolog. Wyzwanie auto/biograficzne). Wiele powodów sprawiło, iż nasza publikacja nabierała pełnego kształtu przez kolejnych kilka lat - jej finalne akcenty (artykuł Iwony Kabzińskiej pt. Torun $z$ oddali (migawki wspomnień) oraz stylizowana na rozmowę wypowiedź Michała Rydlewskiego i Marcina Kafara, poświęcona kwestii nieoczywistych pól znaczeń oplatajacych metafore „prawdziwego zmyślenia”) to teksty datowane na koniec roku 2015. Wcześniej zaś wystapienia konferencyjne przeformułowane zostały do postaci pełnowymiarowych artykułów (co w większości przypadków wymusiło również zmianę ich tytułów), a uzupełniły je teksty Natalii Bloch (O pożytkach płynacych z przypadków, szwendania sie $i$ nomadologii. Autorefleksyjny reportaż antropologiczny) oraz Anny Kacperczyk („Nie muszę się tak bać!”. Rola autoetnografii $w$ analizie emocjonalnych aspektów działania wspinaczkowego), napisane specjalnie na potrzeby niniejszej pracy.

\section{$\cos$}

Prezentowana książka podzielona jest na trzy części odpowiadające trzem korespondujacym ze sobą warstwom tematycznym: (i) aspektom biografii naukowych rozpiętych na szerokim łuku doświadczeń wykraczających poza obszar mieszczący się ściśle w zakresie tzw. badań empirycznych (Część I); (ii) biografiom naukowym związanym $z$ doświadczeniami „terenowej” praktyki badawczej (Część III); (iii) biografiom naukowym sytuującym się na przecięciu wyróżnionych wyżej horyzontów, w połączeniu $z$ horyzontem dodatkowym, a mianowicie literatura (Część II).

Część I otwiera esej Andrzeja P. Wejlanda poświęcony intrygującym kwestiom „małych autobiografii”. Autor - scalajac poetykę zwiewnej opowieści $z$ chirurgiczna precyzja myśli - rozpoczyna swój wywód od semantycznego rozbioru frazy „patrzeć na świat jak antropolog"; pozwala mu to na wyodrębnienie epistemologicznych pozycji nowicjusza, eksperta i rewelatora, znajdujacych odzwierciedlenie w hierarchii statusów uprawomocnianej w praktykach antropologicznej wspólnoty dyskursu. Pozycje te - o czym dowiadujemy się podążając śladem odkrycia Wejlandowskiego - przekładają się na przyjęcie określonych autobiograficznych postaw (Au- 
tor idzie w tym miejscu tropem znanych rozstrzygnięć Małgorzaty Czermińskiej (2000), zachęcajacej, by rozpatrywać autobiografie wedle teoretycznego modelu trójkąta, na który składają się postawy świadectwa, wyznania oraz wyzwania). Najbardziej zajmująca dla Wejlanda okazuje się być postawa wyzwania, zaplatająca się z pozycja rewelatora; dowody na istnienie tego rodzaju zależności kryja się w arcyciekawych, zwykle jednak traktowanych przez nas „po macoszemu” paratekstach: wstępach, posłowiach, apendyksach, wprowadzeniach czy przedmowach do głównych partii ksiażek. Dla rewelatorów natomiast, jak sugeruje Autor szkicu, sa one nieoceniona przestrzenią tekstualną; to właśnie w niej dokonywać się bowiem moga - poprzez wykorzystanie form "małych autobiografii” - akty objawiania naukowemu światu „wielkich wyzwań”.

Choć Andrzej P. Wejland nie odwołuje się w swoich rozważaniach bezpośrednio do tego kontekstu, wydaje się, że uprawnionym byłoby osadzenie jego konceptu w ramach antropologicznej perspektywy refleksywnej i to w podwójnym sensie: po pierwsze, podawane przez Autora przykłady rewelatorskich autobiograficznych postaw wpisują się w ciąg „zaciemnianych" wymiarów etnografii jako wspólnotowej praktyki dyskursywnej (Myerhoff, Ruby 1982; por. też Kafar 2004, 2010) ${ }^{4}$, po drugie, sam tekst Patrzeć na swiat jak antropolog stanowi autobiograficzne wyzwanie; pikanterii temu subtelnemu gestowi intelektualnej prowokacji dodaje fakt, $\mathrm{iż}$, moim zdaniem, staje się on w pełni jasny dopiero na tle innych Wejlandowskich prac, współtworzac wraz z nimi świadectwo nawrócenia na „antropologiczna antropologię" lub, jak ją nazywa Autor Epifanii codzienności, antropologię „Z człowiekiem w środku” (Wejland 2010: 156).

Drugi zartykułów zamieszczonych w Części I przygotowała Danuta Urbaniak-Zając. Jest to „refleksja metodologiczno-biograficzna” skonstruowana w oparciu o schemat retrospekcyjno-analityczny,

${ }^{4}$ Barbara Myerhoff i Jay Ruby (1982: 17-22) łącza autobiograficzne genry wypowiedzi z kategoria „refleksywności” i zaznaczaja, iż mniej więcej do czasu ukazania się pod koniec lat 60. ubiegłego wieku Dzienników Bronisława Malinowskiego, pojawiały się one (sic!) w uwagach wstępnych do dzieł antropologów, względnie w przedmowach, postscriptach etc. Tropy autobiograficzne lub quasi-autobiograficzne dają się odszukać w wielu pracach pisanych poza głównym nurtem dyskursu antropologicznego, zaś akcenty kryptoautobiograficzne znajdziemy w tekstach uznawanych za klasyczne, np. w Smutku tropików Claude'a Lévi-Straussa czy Grach społecznych, polach, metaforach Victora Turnera (Kafar 2010); za sztandarowy przykład polskiej pracy o takim charakterze uchodzi Społeczność wiejska Kazimiery Zawistowicz-Adamskiej (Kafar 2007, 2011c). 
gatunkowo odpowiadajacy autobiografii intelektualnej (por. Ricoeur 2005). Dwie płaszczyzny narracyjne przenikają się tutaj, tworząc linearna opowieść, która - w zależności od przyjętego punktu widzenia - można postrzegać albo jako nieoficjalna „małą historię" myśli pedagogicznej w Polsce, albo jako „prywatna historię” niepokornego, dociekliwego badacza, podejmującego, by posłużyć się językiem Andrzeja P. Wejlanda, „wielkie wyzwanie”. Autorka rozpoczyna artykuł od przywołania epizodu związanego $z$ kończeniem przez siebie doktoratu $z$ pedagogiki społecznej. Perypetie, jakie towarzyszyły Danucie Urbaniak-Zając (niezakwalifikowanie przez jednego $z$ recenzentów pracy jako dysertacji doktorskiej - co ważne, recenzent ów reprezentował psychologię) traktowane sa jako pretekst do krytycznego odniesienia się do dominującego w pedagogice kilka dekad temu „stylu myślowego”. Styl ten zaplatał się z polem specyficznie pojmowanych badań empirycznych, przy uwzględnieniu obowiazującego w nim zestawu wytycznych o charakterze „metodycznym”, nie zaś „metodologicznym”.

Odpowiedni sposób przeprowadzenia argumentacji w Refleksji metodologiczno-biograficznej ujawnia podnoszona przez Ludwika Flecka (Autorka szuka inspiracji w promowanych przez niego ideach) zmienna w czasie strukturę zależności zachodzących między różnymi aspektami tego, co kolektywne, jednostkowe i dyskursywne (Fleck 2007b [1947], 2007c [1960]). Takie rozłożenie akcentów umożliwia np. dostrzeżenie w konieczności poprawienia tekstu doktoratu, o czym opowiada Autorka, doświadczenia co prawda odciskającego silne piętno na jej biografii osobistej, ale w punkcie startu mało znaczacego dla biografii badawczej („opisane doświadczenie bardzo istotne biograficznie (prowadzące do utraty pewności siebie, budzace watpliwości co do zasadności wyboru drogi zawodowej itp.) było w tamtym okresie w zasadzie bezużyteczne dla mojego rozwoju jako badacza" - czytamy). Dalsza praca retrospekcyjna wiedzie Danutę Urbaniak-Zając ku „wtórnemu rozbudzeniu świadomości" w rozumieniu Stephena Critesa ${ }^{5}$ (2001: 43); w przedstawianej autobiografii intelektualnej przyjmuje ono postać naukowej konwersji z pozycji "metodyka” na pozycję „analityka-metodologa” i postrzegane jest jako „naturalna” wypadkowa równoważnych względem siebie czynników takich jak: przekształcenia instytucjonalne, kontakty $z$ innymi „kolektywami myślowymi” (Autorka m.in.

5 „Konwersja jest drugim przebudzeniem (reawakening) człowieka, przebudzeniem jego świadomości. Człowiek po konwersji musi zmienić styl, musi tańczyć w nowym rytmie" - pisze filozof (Crites 2001: 43). 
podkreśla wage jej współpracy $z$ badaczami $z$ Niemiec), komunitarna otwartość na „nowe wyzwania” i personalne predyspozycje do stawienia czoła tym ostatnim („Otwarcie na różnorodność stało się dla mnie/dla nas punktem wyjścia do kruszenia większych i mniejszych barykad" - przyznaje Danuta Urbaniak-Zajacc).

Następną odsłonę Części I wypełnia „autorefleksyjny reportaż antropologiczny" w wydaniu Natalii Bloch. Poznańska badaczka wykorzystuje kategorię trudna do przyjęcia przez klasyczną odmianę nauki, czyli „przypadek” (ang. serendipity), aby - czyniąc z pozornie błahego chwytu retorycznego poręczne narzędzie poznawcze - spróbować wyznaczyć trajektorię swoich losów naukowych. Wsłuchując się w autobiograficzny głos Clifforda Geertza, Autorka tekstu $O$ pożytkach $z$ przypadków, szwendania się $i$ nomadologii dokonuje istotnego dla siebie samej odkrycia: oto dopiero spogladajac wstecz potrafię zobaczyć, co robiłam (wciąż nie będąc pewna, czy w pełni jestem w stanie „objać to wzrokiem”).

Czytając tekst Natalii Bloch trzeba być nad wyraz ostrożnym. W tym wypadku łatwo ulec uwodzicielskiemu tonowi języka, który wespół $z$ wyjątkową plastycznościa toczonej opowieści bierze nas w perswazyjne władanie; wówczas zaciemnia się drugie dno przesłania, jakie zdaje się przyświecać Autorce: „Moja droga do antropologii, a następnie do antropologii mobilności - uchodźstwa, migracji i turystyki - to splot przypadkowych odkryć oraz kombinacji woli i możliwości podążania za nimi” - wyznaje. Czyżby zatem w antropologii, o jakiej mowa rzeczywiście chodziło wyłacznie o serendipity - o czysty traf dla trafu? Owszem, nomadologia jako strategia antropologicznego eksplorowania świata ma polegać i na „szwendaniu się”, i na zdaniu się na „przypadki”, lecz te bez wspomnianych „kombinacji woli i możliwości podążania za nimi” nie byłyby niczym więcej niż zdarzeniami przełamującymi rutynę codzienności. W „przypadku” trzeba umieć rozpoznać „szansę”, odtąd „przypadek” zamienia się w „znak” (Skarga 2002), a ten, za przyzwoleniem Natalii Bloch, staje się przeznaczeniem, o ile nie - ponownie - koniecznościa podjęcia mniejszego lub większego (antropologicznego) wyzwania. Siedem zwrotów życiowo-badawczych wyliczonych przez Autorkę w trybie reportażowej quest narrative to efekt - mam nadzieję, iż nie popełniam przewiny nadinterpretacji - jej „ruchomego” (nomadycznego) wypatrywania sytuacji składajacych cichą obietnicę egzystencjalno-poznawczej niespodzianki.

Część I domyka wspomnieniowy esej Iwony Kabzińskiej pt. Toruń $z$ oddali (migawki wspomnień). Autorka realizuje w nim wyłożoną już gdzie indziej dewizę, mówiąca o tym, że „historię dyscypliny 
tworzą także autoetnografie" (Kabzińska 2013: 46). Tekst Iwony Kabzińskiej to wynik - podobnie jak dzieje się to u pozostałych współautorów naszej ksiażki - refleksywnego nastawienia; tym razem ukierunkowane jest ono na poznawanie samego siebie poprzez spotkania. Jakie spotkania? Kogo $z$ kim lub czym? Kiedy po pierwszej lekturze roboczego wariantu Torunia $z$ oddali wykonywaliśmy $z$ Iwoną Kabzińską współdzieloną pracę interpretacyjną doszedłem do wniosku, iż są to spotkania $z$ miejscami, rzeczami i ludźmi. Ona odnalazła też wymiar spotkania ze soba z przeszłości, a ja, po ponownym uważnym przeczytaniu Migawek wspomnień, uzupełniłem go o wymiar Jej spotkań z myślami. Wszystkie one tworza paletę spotkań wpisaną w chronotop drogi (Bachtin 1982: 470-473); $\mathrm{w}$ sensie dosłownym jest to wahadłowa droga między Warszawa (gdzie Autorka mieszka na stałe) a Toruniem, dokąd w rytmie cotygodniowym udawała się, by spełniać obowiązki nauczyciela akademickiego. Niepostrzeżenie, w autobiograficznej opowieści, realna, chciałoby się rzecz - horyzontalna droga zamienia się w wertykalna podróż w głąb siebie $e^{6}$; wrażane greckimi słowami gnothi seauton - poznawanie siebie zaczyna znaczyć tu w takim samym stopniu odsłanianie prawdy o sobie co, przenoszac nas na stronę etykalna, troskę o siebie (w świecie helleńskim oddawana za pomoca pięknie brzmiącego zwrotu epimeleia heautou) (Skarga 2002: 177; por. także Foucault 2010: 281-306).

Iwona Kabzińka poznaje siebie i troszczy się o siebie poznając i troszcząc się o "scenę" (świat materialny) i o "Drugiego" (świat ludzki) (Tischner 2006). Tak oto, będąc człowiekiem formuje siebie jako podmiot ${ }^{7}$. Czytelnik udając się wraz z Autorką w podróż przechodzi przyśpieszony kurs „pedagogiki miejsca” (Mendel 2006)

6 Wyróżniając słówko „siebie” zgrywam się ze znakomitymi intuicjami Romy Sendyki, która kulturę przełomu wieków XX i XXI określa jako naznaczoną przez „Zwrot ku sobie”. Krakowska badaczka podkreśla, iż, jej zdaniem, rosnąca dziś popularność myślenia trybem zwrotnym jest wyrazem „pewnej zmiany o ogólniejszej naturze: byłby to ruch od "kultury ja» ku "kulturze siebie»; od (złudnej) autonomii ku afirmowanej relacyjności; od koncepcji człowieka jako indywiduum ku człowiekowi "usieciowionemu». Byłby to swego rodzaju zwrot kopernikański - ja z centrum wszechświata staje się jednym $z$ wielu elementów (...) splątanej konstelacji” (Sendyka 2015: 16; kursywa w oryginale).

7 „Słowo "człowiek" wskazuje na byt, podmiot - na relacje, na działanie, myślenie, postępowanie, na sprawianie czegoś, odnoszenie się do czegoś. Pytając o człowieka, pytamy o kogoś, o to, kim jest; pytanie o podmiot zmierza ku temu, jak jest, a więc nie ku istocie, lecz ku sposobom bycia i warunkom, w jakim to bycie spełnić się może. Całkowitego jednak rozdzielenia tych dwóch problematyk osiagnąć się nie da" - wyjaśnia Barbara Skarga (2002: 177). 
i „antropologii niedyskursywnej” (Majbroda 2013), poruszając się po nasyconym wyjątkową wrażliwością opowiadanym mu Toruniu. Wędrujemy po Starym Mieście, przemykamy wieczorową porą między jedna a druga dzielnica (nie wiadomo, dlaczego wczoraj nas one zachwycały i wywoływały poczucie bycia „u siebie”, dziś zaś pieczętuja nieomal kosmiczna "obcość Obcego"), wdychamy zapach sosen w „okolicach DS-u”, wyobrażamy sobie fakturę uniwersyteckich foteli „w ciepłym kolorze pomarańczowym”, smakujemy „toruńskiego serniczka” i „katarzynek”... Spotykamy ludzi: pania $z$ portierni w DS-ie, życzliwych kolegów $z$ Katedry i studentów - przede wszystkim studentów. To relacja ze studentami stawiana jest przez Iwonę Kabzińska ponad inne relacje. W przybliżanej historii nie bez powodu pojawia się zdanie: „Uczyliśmy się od siebie nawzajem"; ufajac w autentyczność celowości ożywiania tego mocno nadwyrężanego obecnie ideału, dostajemy tekstualny dowód jego trwania. Zainteresowanie konkretnymi osobami zaczyna się już w momencie pierwszego kontaktu $z$ nimi (udział w pracach komisji egzaminacyjnej), a znajduje dopełnienie w procesie uczenia Innych, i równoległym względem niego, procesie uczenia Siebie, albo lepiej byłoby powiedzieć - budowania Siebie. Pojawiajaca się tu symetria dawania i brania (Zawistowicz-Adamska 1948: 134-135) sprzyja podtrzymywaniu prawdziwie wspólnotowych więzi nawet wtedy, gdy sytuacja formalna temu nie sprzyja (Autorka zmuszona była rozstać się $z$ akademickim Toruniem w 2011 roku). Odpowiedzialność, wierność drugiemu, sprostanie fundamentom etosu pracy $z$ innymi i dla innych aż do końca („Z wdzięcznościa myślę o tych, którzy pozwolili mi dokończyć prowadzenie seminarium magisterskiego. Uchroniło to osoby, które zaczęły pisać prace pod moim kierunkiem przed koniecznościa zmiany promotora") to aktualnie wartości mało poważane w podlegającym radykalnym zmianom akademickim świecie (może lepszym określeniem byłoby „akademickim światku”), tym bardziej więc cenne są świadectwa, jak to Iwony Kabzińskiej, przekonujące, że sens tego, co robimy nie przysługuje mitycznym skrawkom przeszłości, lecz spełnia się w konstytutywnej dla nas teraźniejszości.

Część II Auto/biograficznych aspektów praktyk poznawczych to próba „wyrażenia niewyrażalnego" (Nycz 2001: 17-49). W pierwszym rzucie podejmuje ją Filip Wróblewski, bioracy na siebie ryzyko eksperymentu literacko-antropologicznego, przekształcającego kanoniczna kategorię nie tylko badań nad kultura - teren - w „model do składania". To w jakiejś mierze obrazoburcze przedsięwzięcie staje się wyjątkowo intrygujące poprzez, by sparafrazować Umberto 
Eco (2007: 157-158), przebijająca $z$ zawartości treściowej wykładanego nam "etnopoematu” hiperboliczną dyspersyjność. Każda fraza, każda najdrobniejsza zbitka pojęciowa, ba, nieomal każde przywołane tutaj słowo działa niczym schody Eschera, wywołując skojarzeniowy „zawrót głowy”. Odbiorca zaprezentowanej pracy - kiedy już oswoi się $z$ formą idąca na przekór jego przyzwyczajeniom co do konwencji wyrażania myśli naukowej i zechce zdobyć się na wysiłek głębokiej lektury - znajdzie w niej nieprawdopodobna mnogość tropów, pobudzających (o ile nie przymuszajacych) go do gruntownego zrekapitulowania wiedzy o tym, czym (lub kim) jest „teren”. Łatwo sobie wyobrazić, iż w zależności od nastawienia, czytelnik Modelu do składania będzie znajdował w owym niestandardowym akcie lektury albo niekryta przyjemność, albo, wręcz przeciwnie - pretekst do wyrażenia świętego oburzenia.

Filip Wróblewski swoim prowokacyjnym wystąpieniem, jawnie przekracza świadomościowy rubikon, transformuje (może lepiej powiedzieć: utekstawia), nadajac jej swoisty znaczeniowy wyraz, epistemologiczna pozycję „antropologa codzienności”, tę przyjmowana przez Rocha Sulimę, a tłumaczoną przez niego w następujący sposób: „Dla antropologa codzienności źródłem jest wszystko, wszystko też jest dla niego terenem. Tym samym status źródła i status terenu przestaje mieć sens. Pozostając przy starym języku etnografów, źródłem i terenem dla antropologa codzienności jest przede wszystkim on sam dla innych i przez to sam dla siebie. Antropolog codzienności "zawsze" jest na badaniach: przy domowym obiedzie, w supermarkecie, w uniwersyteckiej kawiarni, na ulicy i podczas snu" (Sulima 2000: 7-8).

Model do składania udowadnia, że status "terenu” ciagle ma sens, choć dziś jest to sens inny niż ten, do którego przywykliśmy przez dziesięciolecia naszej praktyki badawczej i przeciwko któremu półtorej dekady temu występował Sulima.

Inne jeszcze oblicze namysłu nad „wyrażaniem niewyrażalnego" pokazuja Marcin Kafar i Michał Rydlewski. Węzłowa staje się dla nich metafora „prawdziwego zmyślenia”, która przetransponowana $z$ obszaru literatury i literaturoznawstwa na grunt refleksywnego spojrzenia na praktykę poznania urasta do rangi znakomitego „wehikułu konceptualnego", dającego sposobność poruszenia statycznych do tej pory przestrzeni dyskursywnych.

Michał Rydlewski w na poły biograficznym, na poły zaś autobiograficznym szkicu pt. Wszyscy jesteśmy wymyśleni stara się wysycić potencjał idiomu „prawdziwego zmyślenia”, źródłowo osadzonego w twórczości Marka Hłaski; uruchamiając klucz kulturo- 
znawczo-filozoficzny przypomina czytelnikowi, iż dla autora Pięknych dwudziestoletnich literatura stanowiła „miejsca autokreacji tożsamości oraz przeplatania się fikcji i rzeczywistości”. Jednocześnie Rydlewski zmusza nas do pamiętania, iż w pisarstwie Hłaskowskim niczym w zwierciadle odbijają się zewnętrzne, polityczno-społeczne uwarunkowania epoki socjalistycznej w powojennej Polsce. Literacki zabieg „prawdy zmyślonej” winien być zatem postrzegany jako strategia radzenia sobie $z$ trudna, o ile nie wręcz niemożliwą do zaakceptowania rzeczywistością. $Z$ perspektywy Hłaski-człowieka i Hłaski-pisarza żyjącego w czasach komunistycznych system ten sam w sobie był „fantastycznie zaaranżowany”. Pomysł opisania owego przesiąkniętego „surrealną dziwnościa” świata daje się więc odczytywać jako podszyty rozpacza symboliczny akt „wzięcia w ramę", czyli przeniesienia w sferę fikcji literackiej przejawów trawiącej go „małości i nędzy”.

W drugiej partii swojego artykułu Michał Rydlewski sprawdza na sobie jako antropologu aktualność bliskiej mu jeszcze w okresie dzieciństwa i dorastania Hłaskowskiej idei „prawdziwego zmyślenia". Po latach przechowywania w zakamarkach pamięci wywoływana jest ona w reakcji na podwójny kryzys: podmiotu indywidualnego (Autora Wszyscy jesteśmy wymyśleni) i podmiotu zbiorowego - wspólnoty antropologów przełomu wieków. Jak odnaleźć siebie w świecie, co do którego mam świadomość jego konwencjonalności? - zastanawia się Rydlewski i zdobywa się na wyznanie: „Wróciłem do Marka Hłaski $z$ nowym pytaniem. Szukałem u niego odpowiedzi, jak żyć z poczuciem swojego własnego "wymyślenia"? Jak, pomimo sztuczności słów wypowiedzianych przez innych, powiedzieć coś szczerze i naprawdę?”. To dylemat, trzeba przyznać, niebagatelny, co więcej, tylko pozornie wyczerpujący się w sferze odczucia indywidualnego. Mamy tutaj bowiem do czynienia $z$ wielkim sproblematyzowaniem motywu do niedawna postrzeganego przez badaczy kultury jako „pełnia ludzkich możliwości” - tak na „świadomość naszej świadomości" patrzyła chociażby Barbara Myerhoff (2010: 32). Autodiagnoza postawiona w Wszyscy jesteśmy wymyśleni z przepełnionego nadzieja pragmatycznego zadowolenia czyni więc egzystencjalne przekleństwo. Czy da się od niego uwolnić? Czy panaceum na nie faktycznie jest prawda „mojej opowieści”? Na te pytania chyba wciąż nie znamy odpowiedzi.

Marcin Kafar ostrze uwagi kieruje na odrębne aspekty „prawdy zmyślonej”. Interesuje go zrekonstruowanie wielowymiarowych zależności istniejących między światem rzeczywistym a fikcjonalnym; pole eksploracji jest nietypowe: sprowadza się mianowicie 
do skrajnie ambiwalentnego doświadczenia, polegającego na zamykaniu „żywego życia” w tekście złożonym ze sporządzanych po raz pierwszy notatek terenowych, a następnie powtórnym odbiorze w życiu pozatekstualnym (toczy się ono w Domu Pomocy Społecznej dla Przewlekle Chorych) tego, co przedtem poddane zostało dyktatowi pisma. Zmieszanie statusu ontologicznego rzeczy pierwotnie należących do rozdzielnych porządków okazuje się wysoce niepokojące (wstrzassowe, jak powiada Autor), ale też rodzi poznawcza ciekawość, co doskonale oddaje następujacy ustęp „Prawdziwego zmyślenia” w praktyce badawczej: „Sądzę, iż, przynajmniej do pewnego stopnia, stan zawieszenia, w jaki (...) popadłem, trwa po dziś dzień, wszelako zmianie uległa perspektywa, wedle której postrzegam rzeczy usytuowane na przecięciu tego, co realne i tego, co utekstualnione, albo inaczej: tego, co poprzez stekstualizowanie przemienia się w osobliwą formę realności, stanowiąc odtąd "prawdę zmyślonąı".

Po „zwrocie tekstualnym” (por. m.in. Clifford, Marcus 1986; Clifford 2000) wiemy doskonale, iż doświadczenie badawcze zawsze zawiera komponent tzw. realnej obecności oraz komponent obecności zapośredniczonej przez myśl i pismo. Marcin Kafar - zgodnie $z$ regułą wstępnych rozpoznan - rozciaga doświadczanie „bycia w terenie" na doświadczanie literatury. W procesie tym towarzyszy mu - pokrewny Markowi Hłasce w jego „zmyśleniowo-prawdziwościowych" intuicjach - amerykański pisarz Paul Auster. Składając przed czytelnikiem raport z lektury Austerowskiej powieści pt. Noc wyroczni (zbudowana jest ona w oparciu o koncept "true false”, anglojęzyczny odpowiednik „prawdziwego zmyślenia”), Kafar wchodzi w obszar „gry narracyjnej”, umożliwiającej mu rozszerzenie horyzontu analitycznego o to, co nie mieści się do końca ani w obrębie „prawdy”, ani w obrębie „fikcji”, zajmując pojemna przestrzeń „pomiędzy", w której na plan pierwszy wysuwa się rys auto/biograficzny (Autor dookreśla go korzystając ze wsparcia Javiera Maríasa, Virginii Woolf, nade wszystko zaś Paula Ricoeura).

W tekście pt. „Prawdziwe zmyślenie” - nieoczywiste pola znaczen metafory literackiej, Michał Rydlewski i Marcin Kafar, występujac $z$ odmiennych pozycji poznawczych, wykorzystują strategię dialogicznej rozmowy, by pokusić się o stopniowe, dwugłosowe przybliżanie idei rozpodobnionej wcześniej w pojedynczych autorskich wypowiedziach. Rozmowa dialogiczna, co słusznie podnosi Loïc J.D. Wacquant (2001: 4-5), „pozwala na skuteczne interweniowanie w środku tekstu, na jego zmianę, na krytykę i dzięki temu umożliwia dialog. Zmuszajac myśliciela do reagowania na myśle- 
nie innych, ucieleśnione przez osobę rozmówcy (...), skłania go do rezygnacji $z$ zamknięcia się $\mathrm{w}$ ramach języka i historycznie określonej tradycji intelektualnej, a zatem do wpisania się w szersza przestrzeń. I w końcu - co najważniejsze - dialog daje czytelnikowi obraz procesu intelektualnego, który doprowadza autora do zajmowanego w danej kwestii stanowiska; pozwala uchwycić jego metodę in actu. Krótko mówiąc, (...) odbiera w jakimś sensie autorowi jego pozycję autorytetu, a czytelnika pozbawia bierności, dostarczając im obu środków komunikacji wolnej od cenzury, która jest wpisana w konwencjonalne formy wymiany myśli naukowej".

Nasz dialog dotyczący metafory "prawdziwego zmyślenia” uzmysłowił nam, jak wysoce złożone problemy kryją się za sklejonymi w przebłysku pisarskiego geniuszu słowami, i jak mocno - to sytuacja paradoksalna $-z$ jednej strony rozmijamy się, $z$ drugiej zaś jesteśmy współbieżni w wypracowywaniu stanowisk odnośnie do Hłaskowskiej i Austerowskiej kategorii „prawdy zmyślonej”. Tytułowe „nieoczywiste pola znaczeń" zderzają dziedzinowe i dyscyplinarne dyskursy - filozoficzny, teoretyczno-kulturowy, antropologiczny, medioznawczy, filologiczny, literaturoznawczy, językoznawczy, historyczny, etyczny; te zaś sprawiaja, iż myśl robi się zwrotna, cyrkulując podważa samą siebie, wybiega w przód zagarniając nowe wątki, po czym zatrzymuje się, zawraca, i zmierza na ukos, a wszystko po to, by finalnie odnaleźć się - tak zwykle bywa w przypadku bytów na wskroś heterotopicznych (Foucault 2005) - w tópos koinós, miejscu wspólnym, przywodzącym do łącznego zaistnienia elementów o cechach przypominajacych te ze słynnej chińskiej encyklopedii Borgesa (Kafar 2011d: 90). Siła oddziaływania heterotopii „prawdziwego zmyślenia” jest ogromna - czy ich czas dopiero nadchodzi?

W Części III Auto/biograficznych aspektów praktyk poznawczych zawarte sa cztery teksty o różnym odcieniu tej samej specyfiki tematycznej, uwzględniającej sytuację nadawania badaniom $z$ zakresu nauk społecznych i humanistycznych podmiotowego charakteru.

Część tę otwiera artykuł Martyny Pryszmont-Ciesielskiej („Ja” badacza $w$ podejściu auto/biograficznym), w której zamyśle leży opracowanie mapy pojęciowej dla badaczy zdecydowanych uzbrajać realizowane przez siebie projekty badawcze $\mathrm{w}$ doświadczenie osobiste. Zakładając, iż biografia ,jest jednym $z$ najbardziej inspirujących źródeł wiedzy na temat świata społecznego" oraz że „stanowi ona również ważny, a zarazem złożony czynnik kształtujący naukę”, Autorka za cel obiera „rekonstrukcję dróg, jakimi może 
zmierzać badacz przekonany o sile oddziaływania własnej biografii na podejmowaną aktywność naukowa”. Podstawowym pytaniem w takim kontekście jest, co zrozumiałe, pytanie o sposób umiejscawiania podmiotu poznającego $\mathrm{w}$ procesie badawczym.

Martyna Pryszmont-Ciesielska wyodrębnia dwie perspektywy: (i) autobiograficzna, gdzie kluczowym punktem odniesienia dla podejmowanej problematyki jest bagaż indywidualnych doświadczeń badacza oraz (ii) auto/biograficzna, osadzona na epistemologicznym postulacie równoważenia doświadczeń własnych $z$ doświadczeniami badanych osób. Wedle proponowanego przez Autorkę podziału pozycje autobiograficzna i auto/biograficzna najmocniej uzewnętrzniają się w podejściach biograficznym, etnograficznym i, zyskującym wśród pedagogów coraz większe metodologiczne zaufanie (Červinková, Gołębniak 2010, 2013), badaniach w działaniu.

Drugim tekstem Części III jest „Nie muszę się tak bać!”. Rola autoetnografii $w$ analizie emocjonalnych aspektów działania wspinaczkowego Anny Kacperczyk, która najpierw drobiazgowo zrekonstruowała, a następnie poddała szczegółowej analizie od strony metodologicznej warstwę osobistych doświadczeń badawczych. Jako wyjściowa ramę konceptualna Autorka przyjmuje osadzone na gruncie etnograficznym badania nad społecznym światem wspinaczy. Pod tym katem rozważane sa wielorakie sposoby radzenia sobie $z$ emocjonalnymi aspektami działania wspinaczkowego, wydobywanymi $z$ obserwacji sytuacji napotykanych $\mathrm{w}$ trakcie badań terenowych, materiałów wideo, zastanych źródeł autobiograficznych, wywiadów $z$ innymi wspinaczami, jak również tworzonych przez Autorkę tekstów autoetnograficznych.

Głównym przedmiotem zainteresowania Anny Kacperczyk sa emocje doświadczane przez wspinaczy bezpośrednio w trakcie czynności wspinaczkowych. Momentem rozbudzenia świadomości co do wagi interpretacyjnej tego wymiaru przeżyć stało się obserwowanie inicjalnej sceny wspinania się przez małego chłopca; scena ta zainspirowała Autorkę do przywołania własnych doświadczeń strachu i do metodycznego odtworzenia ich za pomoca pisarstwa autoetnograficznego oraz notatek sporzadzanych na poczatku swojej kariery wspinaczkowej. Dalszy proces poszukiwań źródeł i ich analizy potwierdził, iż nie sa to doświadczenia odosobnione; należą one do „naturalnego” wyposażenia kulturowo-społecznego świata wspinaczy, majacych określony repertuar zachowań mentalnych służących pokonywaniu strachu.

Auto/biograficznej stronie badań empirycznych poświęcone są także dwa pozostałe teksty zamieszczone w naszej książce. 
Pierwszy z nich, $O$ (nie)udanej próbie odnalezienia się $w$ roli praktykujacego badacza. Refleksje $z$ pola praktyki, autorstwa Izabeli Kamińskiej to refleksywny (albo, jak chce tego Autorka, autorefleksyjny) szkic zawierajacy wnikliwa analize „ja” badaczki, doznajacej „zmieszania” tożsamościowego, wynikającego z konieczności równoległego operowania w świecie społecznej praktyki (występowanie w roli asystenta rodziny) i świecie akademickim (wchodzenie w rolę badacza). Tekst uzewnętrznia trudności, jakich Kamińska doświadczyła, próbując pogodzić $w$ sobie skrajnie momentami kontradykcyjne plany dyskursywne, ujęte za pomoca obrazowego oksymoronu "praktykujacego badacza”. W istocie rzeczy, „praktyk” i „badacz” okazuja się być figurami przypisanymi do przeciwległych biegunów, odpowiadających odmiennym postawom: postawie uczestnika oraz postawie obserwatora. Podstawowy, wyrosły w czasie rzeczywistym dylemat Autorki sprowadzał się do możliwości przekroczenia owego paradoksu postaw, skutecznie utrudniajacego jej prowadzenie badań i jednoczesne pozostanie wierną sobie w kwestii odpowiedzialności za osoby, z którymi pracuje „w terenie”. Szansa na przełamanie metodologiczno-etycznego impasu wyłoniła się w zmianie podejścia badawczego $z$ „badań w działaniu” na „badania przez działanie"; to $z$ kolei, w jej zamyśle, miało dać sposobność wykształcenia odpowiedniej postawy epistemologicznej, umożliwiającej owocna realizację rozpoczętego projektu. Efekt decyzji podjętej przez Izabelę Kamińska był zaskakujacy dla niej samej, pozwolił bowiem, owszem, zyskać dużą dozę samoświadomości (badawczej), wciąż jednak nie rozstrzygnął wszystkich wątpliwości co do słuszności działań podejmowanych względem siebie i innych.

Rozpatrywany na metapoziomie artykuł $O$ (nie)udanej próbie odnalezienia sie $w$ roli praktykujacego badacza stanowi wyraz dokonujących się przemian, jakie w ciagu ostatnich dwóch dekad zachodza w dyscyplinarnej świadomości pedagogiki. Zarówno to wystapienie, jak i omawiane wcześniej wystapienie Danuty Urbaniak-Zając objawiają rośnięcie w siłę „humanistycznie zorientowanej pedagogiki”, która przepowiedział w swoich pracach Dariusz Kubinowski (por. m.in. Kubinowski 2006, 2010; Kubinowski, Nowak 2006).

Drugi, a zarazem ostatni ze szkiców, z jakimi przyjdzie obcować w tej książce Czytelnikowi, to nastrojony „humanistycznie” dwugłos Edyty Januszewskiej (pedagoga) i Izabeli Lewandowskiej (historyka), prezentujący spektrum podejść, które zdaja się podpadać pod wytyczne przypisane przez Sławomira Krzychałę (2007: 19-20) figurze „obserwujacego obserwatora”: „Obserwatorem jest tu badacz, a rekonstrukcja procesu badawczego przekracza jego obserwacje 
i związane $z$ nią interpretacje i kategoryzacje. Obserwacja obserwatora przenosi dyskurs metodologiczny na inny poziom, gdy perspektywa obserwacji, logika interpretacji i procedura kategoryzacji, krótko mówiąc - sama praktyka badawcza poddana zostaje obserwacji, interpretacji i kategoryzacji" (zapis zgodny $z$ oryginałem).

Autorki artykułu Badacz wobec badanego. Różne dyscypliny - jedna perspektywa skupiają się na relacji badacz - badany, relacji uwikłanej w „kontekst sytuacyjny i głęboko zakorzenionej w perspektywie społecznej i humanistycznej". Spoiwem toczonych rozważań jest tutaj współdzielony (chciałoby się rzec - auto/biograficzny) korpus doświadczeń zorientowanych na: (i) uwarunkowania roli badacza, (ii) terapeutyczne aspekty sytuacji badawczej, (iii) czynniki utrudniajace podtrzymywanie relacji badacz - badany, (iv) przełamywanie barier relacyjnych, wreszcie, (v) dylematy etyczno-moralne, pojawiające się w kontekście podejmowanych zobowiązań badawczych.

\section{$\cos$}

W znakomitym eseju pt. Mroczek: zapominanie i pomijanie $w$ nauce, Oliver Sacks, zastanawiając się nad zaskakującymi źródłami regresu w nauce, pisał: „Co sprawia, że dana obserwacja czy nowa idea jest akceptowana, dyskutowana, zapamiętywana? Co może temu zapobiec, nawet jeśli jest ona w sposób oczywisty ważna bądź wartościowa?

Freud w odpowiedzi na to pytanie podkreśliłby znaczenie wewnętrznego oporu: nowa idea wydaje się bardzo groźna czy odstręczająca, więc nie pozwala się jej na pełny dostęp do umysłu. Bez wattpienia tak bywa, lecz to wyjaśnienie sprowadza wszystko do psychodynamiki i motywacji; nawet w psychiatrii potrzeba czegoś więcej.

Nie wystarczy bowiem tylko spostrzec, "uchwycić" coś w mgnieniu oka. Umysł musi to sobie przyswoić, zatrzymać. Wydaje mi się, że ten proces przyswojenia, tworzenia przestrzeni mentalnej - formułowania kategorii potencjalnie połaczonej $z$ innymi (oraz gotowość do takiej aktywności) maja kluczowe znaczenie dla określenia, czy dana idea lub dane odkrycie zakorzenia się i zaowocują, czy też raczej zostaną zapomniane: zwiędną i uschna bezpotomnie. Pierwsza trudność - pierwsza bariera - tkwi w naszym umyśle: musimy umieć otworzyć się na nowe idee, a potem uświadomić je sobie trwale i w pełni; musimy nadać im formę pojęciową i utrzy- 
mać je w umyśle nawet wtedy, gdy nie pasują do naszych poglądów, przekonań czy kategorii (albo sa z nimi sprzeczne)" (Sacks 1996: 107-108).

Czy Auto/biograficzne aspekty praktyk poznawczych zasługuja na potraktowanie ich jako przyczyniajacych się do konstytuowania się nowego dyskursu o nauce? Dyskursu zaplecionego wokół idei refleksywności rozumianej tak, jak chcieli tego Barbara Myerhoff i Jay Ruby (1982: 18), gdy mówili: „Nauka jest refleksywna tak długo jak długo jej odkrycia pozostaja zwrotne wobec systemu, w którym sa objaśniane, rzucając światło na środek umożliwiający ich zgromadzenie" (kursywa moja - M.K.). Dyskursu doceniającego wage pierwiastka osobowego w tworzeniu wiedzy i utrzymywaniu moralnej otoczki prowadzonych przez nas badań. Dyskursu zyskującego prawomocność w auto/biograficznych postawach, odciskających swe piętno na działaniach badawczych i ich (tekstualnych) skutkach. Dyskursu nobilitującego autorskie sygnatury, uzasadnione obecnością żywych ludzi w tym, co zwiemy „światem naukowym”.

Ocenę tę pozostawiam Czytelnikowi, życząc Mu, wraz z pozostałymi współautorami tej pracy, by czas, jaki poświęci na jej lekturę, nie był czasem straconym...

\section{Bibliografia}

Bachtin M.

1982 Formy czasu i czasoprzestrzeni w powieści, [w:] M. Bachtin, Problemy literatury $i$ estetyki, przeł. W. Grajewski, Warszawa, s. 278-488.

Bourdieu P., Wacquant L.J.D.

2001 Zaproszenie do socjologii refleksyjnej, przeł. A. Sawisz, Warszawa.

Červinková H., Gołębniak B.G. (red.)

2010 Badania $w$ działaniu. Pedagogika $i$ antropologia zaangażowane, Wrocław.

2013 Edukacyjne badania w działaniu, Warszawa.

Clifford $\mathrm{J}$.

2000 Kłopoty $z$ kultura. Dwudziestowieczna etnografia, literatura i sztuka, przeł. E. Dżurak, J. Iracka, E. Klekot, M. Krupa, S. Sikora, M. Sznajderman, Warszawa.

Clifford J., Marcus G.E.

1986 Writing culture. The poetics and politics of ethnography, Berkeley-Los Angeles-London. 
Crites S.

2001 The narrative quality of experience, [w:] L.P. Hinchman, S.K. Hinchman (red.), Memory, identity, community. The idea of narrative in the human sciences, Suny, s. 26-50.

Czermińska M.

2000 Autobiograficzny trójkąt. Świadectwo, wyznanie $i$ wyzwanie, Kraków.

Eco U.

2007 Sześć przechadzek po lesie fikcji, przeł. J. Jarniewicz, Kraków. Fleck L.

2007a [1938] Zagadnienie teorii poznawania, [w:] L. Fleck, Style myślowe i fakty. Artykuły i świadectwa, S. Werner, C. Zittl, F. Schmaltz (red.), Warszawa, s. 215-251.

2007b [1947] Patrzeć, widzieć, wiedzieć, [w:] L. Fleck, Style myślowe i fakty. Artykuły i świadectwa, S. Werner, C. Zittl, F. Schmaltz (red.), Warszawa, s. 163-184.

2007c [1960] Kryzys $w$ naukach przyrodniczych. Ku naukom przyrodniczym wolnym i bardziej ludzkim, [w:] L. Fleck, Style myślowe $i$ fakty. Artykuły i świadectwa, S. Werner, C. Zittl, F. Schmaltz (red.), Warszawa, s. 185-191.

Foucault M.

2010 Troska o siebie, [w:] M. Foucault, Historia seksualności, przeł.

B. Banasiak, T. Komendant, K. Matuszewski, wstępem opatrzył

T. Komendant, Gdańsk, s. 281-306.

Kabzińska I.

2013 „Babska etnologia”, [w:] B. Bossak-Herbst, M. Głowacka-Grajper, M. Kowalski (red.), Antropologiczne inspiracje. Księga jubiKafar M. leuszowa dla Profesor Ewy Nowickiej, Warszawa, s. 36-58.

2004 Od spotkania do wspólnoty. Autobiograficzny raport z terenu, „Eódzkie Studia Etnograficzne”, t. 43, numer tematyczny: Codzienne i niecodzienne. O wspólnotowości $w$ realiach dzisiejszej Łodzi, G. Karpińska (red.), s. 79-101.

2007 Projekt „etnografii doświadczenia” Kazimiery Zawistowicz-Adamskiej i jego współczesne zastosowania, „Lud”, t. 91, s. 111135.

2010 Zwroty zapoznane - zwroty dokonane. Autobiografia w myśleniu etnograficznym $i$ antropologicznym, [w:] J. Kowalewski, W. Piasek (red.), „Zwroty” badawcze w humanistyce. Konteksty poznawcze, kulturowe $i$ społeczno-instytucjonalne, Olsztyn, s. 211-235.

2011a Wprowadzenie, [w:] M. Kafar (red.), Biografie naukowe. Perspektywa transdyscyplinarna, Łódź, 7-12.

2011 b (red.), Biografie naukowe. Perspektywa transdyscyplinarna, Łódź. 
2011c O wspótuczestnictwie i osobistym ethosie $w$ kontekście Społeczności wiejskiej Kazimiery Zawistowicz-Adamskiej, „Łódzkie Studia Etnograficzne", t. 50, numer tematyczny: Wokół społeczności wiejskiej. Etnografia Kazimiery Zawistowicz-Adamskiej - kontynuacje i inspiracje, G. Karpińska, A. Nadolska-Styczyńska (red.), s. 175-190.

2011d Michel Foucault jako heterotopia, [w:] M. Kafar (red.), Biografie naukowe. Perspektywa transdyscyplinarna, Łódź, s. 85-100.

2013a Around „Biographical Perspectives”. An introduction, [w:] M. Kafar (red.), Scientific biographies. Between the "professional” and "non-professional" dimensions of humanistic experiences, ŁódźKraków, s. 7-20.

2013b (red.), Scientific biographies. Between the "professional” and "non-professional" dimensions of humanistic experiences, ŁódźKraków.

2013c W świecie wygnańców, wdów i sierot. O pewnym wariancie antropologii zaangażowanej, Łódź.

Kafar M., Modrzejewska-Świgulska M. (red.)

2013 Autobiography - biography - narration. Research practice for biographical perspectives, Łódź-Kraków.

Krzychała S.

2007 Projekty życia. Młodzież $w$ perspektywie badan rekonstrukcyjnych, Wrocław.

Kubinowski D.

2006 Pedagogiczne myślenie humanistyczne jako kategoria metodologiczna, [w:] D. Kubinowski, M. Nowak (red.), Metodologia pedagogiki zorientowanej humanistycznie, Kraków, s. 171180.

2010 Metodologia spod znaku $x^{2}$ a humanistyczna tożsamość pedagogiki, [w:] J. Piekarski, D. Urbaniak-Zając, K.J. Szmidt (red.), Metodologiczne problemy tworzenia wiedzy $w$ pedagogice. Oblicza akademickiej praktyki, Kraków, s. 79-90.

Kubinowski D., Nowak M. (red.)

2006 Metodologia pedagogiki zorientowanej humanistycznie, Kraków. Kuhn T.S.

1985 Dwa bieguny. Tradycja i nowatorstwo w badaniach naukowych, przeł. i posł. opatrzył S. Amsterdamski, Warszawa.

2003 Droga po strukturze. Eseje filozoficzne z lat 1970-1993 i wywiad rzeka $z$ autorem słynnej "Struktury rewolucji naukowych”, podali do druku J. Conant i J. Haugeland, przeł. S. Amsterdamski, Warszawa.

Lévinas E.

2008 O Bogu, który nawiedza myśl, przeł. M. Kowalska, Kraków. Lévi-Strauss C.

2010 Smutek tropików, przeł. A. Steinsberg, Warszawa. 
Majbroda K.

2013 Drogi wiedzy w antropologii społeczno-kulturowej po zwrocie ku sensoryczności $i$ niedyskursywnemu doświadczaniu rzeczywistości, „Lud”, t. 97, s. 17-38.

Marcel G.

1987 Dziennik metafizyczny, wybrał K. Tarnowski, przeł. E. Wende, przekł. oprac. S. Cichowicz, Warszawa.

Mendel M. (red.)

2006 Pedagogika miejsca, Wrocław.

Myerhoff B., Ruby J.

1982 Introduction, [w:] J. Ruby (red.), A crack in the mirror. Reflexive perspectives in anthropology, Philadelphia, s. 1-38.

2010 Stories as equipment for living. Last talks and tales of Barbara Myerhoff, [w:] M. Kaminsky, M. Weiss (red.), we współpracy z D. Metzger, słowo wstępne J. Kugelmass, wprowadzenie Th. Cole, Ann Arbor.

Nycz R.

2001 Literatura jako trop rzeczywistości, Kraków.

Ricoeur P.

2005 Refleksja dokonana. Autobiografia intelektualna, przeł. P. Bobowska-Nastarzewska, Kęty.

Sacks O.

1996 Mroczek: zapominanie i pomijanie w nauce, [w:] O. Sacks, J. Miller, S.J. Gould, D.J. Kevles, R.C. Lewontin, Ukryte teorie nauki, przeł. A. Pawelec, Kraków, s. 93-122.

Sendyka R.

2015 Od kultury ja do kultury siebie. O zwrotnych formach $w$ projektach tożsamościowych, Kraków.

Skarga B.

2002 Ślad i obecność, Kraków.

Sulima R.

2000 Antropologia codzienności, Kraków.

Tischner J.

2006 Filozofia dramatu, Kraków.

Turner V.

2005 Gry społeczne, pola, metafory. Symboliczne działanie $w$ społeczeństwie, przeł. W. Usakiewicz, Kraków.

Wacquant L.J.D.

2001 Słowo wstępne, [w:] P. Bourdieu, L.J.D. Wacquant, Zaproszenie do socjologii refleksyjnej, przeł. A. Sawisz, Warszawa, s. 3-7.

Wejland A.P.

2010 Latem w parku. Epifanie codzienności, [w:] R. Godula-Węcławowicz (red.), Lato $w$ mieście. Różne oblicza kultury, WarszawaKraków, s. 145-162.

Zawistowicz-Adamska K.

1948 Społeczność wiejska. Doświadczenia i rozważania z badań terenowych w Zaborowie, Łódź. 